\title{
CHIMERIC ANTIGEN RECEPTOR FOR CHRONIC LYMPHOCYTIC LEUKEMIA - A REVIEW
}

\author{
KIRUTHIGA RAGHUNATHAN ${ }^{1}$,BRINDHA DEVI P
}

${ }^{1}$ Department of Bioengineering, B. Tech Biotechnology, School of Engineering, Vels Institute of Science, Technology and Advanced Studies, Chennai - 600 117, Tamil Nadu, India. ${ }^{2}$ Department of Bioengineering, School of Engineering, Vels Institute of Science, Technology and Advanced Studies, Chennai - 600 117, Tamil Nadu, India. Email: pbrindhadevi@gmail.com

Received: 10 September 2018, Revised and Accepted: 13 November 2018

\begin{abstract}
Chronic lymphocytic leukemia cancer is a deadly one which affects the bone marrow from making it to produce more amounts of white blood cells in the humans. This disease can be treated either by radiation therapy, bone marrow transplantation, chemotherapy, or immunotherapy. In radiation therapy, the ionizing radiation is used toward the tumor cells, but the main drawback is the radiation may affect the normal cells as well. To overcome this drawback, immunotherapy chimeric antigen receptor (CAR) is used. These CAR cells will target only the antigen of the tumor cells and not damage the normal cells in the body. In this therapy, the T-cells are taken either from the patients or a healthy donor and are engineered to express the CARs which are called as CAR-T-cells. When these CAR-T-cells come in contact with the antigen present on the surface of the tumor cells, they will get activated and become toxic to the tumor cells. This new class of therapy is having a great prospect in cancer immunotherapy.
\end{abstract}

Keywords: Chimeric antigen receptor, Chronic lymphocytic leukemia, Immunotherapy.

(C) 2019 The Authors. Published by Innovare Academic Sciences Pvt Ltd. This is an open access article under the CC BY license (http://creativecommons. org/licenses/by/4. 0/) DOI: http://dx.doi.org/10.22159/ajpcr.2019.v12i1.29642

\section{INTRODUCTION}

Chronic lymphocytic leukemia (CLL) cancer is a deadly one which affects the bone marrow from making it to produce more amounts of white blood cells in the humans $[66,67,73]$. The lymphocytes consist of natural killer cells, B-cells, and T-cells. The bone marrow produces both T-cells and B-cells, but the maturation of T-cells takes place in the thymus and maturation of B-cells takes place in the bone marrow. When these lymphocytes are produced in large amount, they get accumulated in spleen, bone marrow, blood, and lymph nodes which results in enlargement of these organs and the hemoglobin content will get decreased $[1,2]$. This can be treated either by radiation therapy, chemotherapy, immunotherapy, or stem cell transplantation. In radiation therapy, the ionizing radiation is used toward the tumor cells, but the main drawback is the radiation may affect the normal cells as well. Initially, in bone marrow transplantation, the patient should be treated with either chemotherapy or radiation therapy and allogeneic bone marrow transplantation, but the infections are major complication [47]. Here, in this review, we have focused the structure, production, evolution of chimeric antigen receptor-T CAR-T-cells, and their role in treating CLL.

\section{CAR-T-CELLS}

The CAR-T-cells are also known as "living drug" [48] as they are engineered with receptor immune cell whose activity is specific toward the cancer cells. The targeting efficiency of these cells is very high as they target only cancer cells and harmless to the normal cells.

Of these therapies, the latest method is CAR-T-cells. In this method, the T-cells are taken either from the patient's blood or from a healthy donor, and then, these cells are genetically engineered to express an artificial T-cell receptor which will target and destroy the cancer cells $[14,72]$.

\section{CAUSES OF CLL}

TheCLLis caused by specificherbicide2,3,7,8-tetrachlorodibenzodioxin. The tetrachlorodibenzo-p-dioxin (TCDD) is a fat-soluble compound in contact with the skin, the compound has ability to enter into the gene of the organisms $[10,76]$. The TCDD binds with the aryl hydrocarbon receptor which is a type of protein present in the gene resulting in gene transcription $[11,12]$. The primary cause of ionizing radiation will break the double-stranded deoxyribonucleic acid (DNA) [13]. Furthermore, the risk factor of this cancer depends on age, family history, gender, and ethnicity. About $90 \%$ of people with CLL are above the age group of 50. First-degree relatives (parents, siblings, or offspring) of people with CLL have more than twice the risk for this cancer. CLL in male is more common when compared to a female. According to ethnicity and recent statistical report, the people in North America and European countries are more likely to be affected by this cancer [77].

\section{AVAILABLE TREATMENT FOR CLL}

\section{Chemotherapy}

To treat CLL, the drug rituximab, fludarabine, and cyclophosphamide against CD20 is used as it inhibits the synthesis of DNA resulting in the suppression of tumor cells. The drug cyclophosphamide is used along with fludarabine and has a side effect of reducing the white blood cell count when taken individually. Hence, the combination of this drug used to treat CLL $[74,75]$. Furthermore, the CLL can be diagnosed only when it is treated at initial stages [3-5].

\section{Radiation therapy}

Radiation therapy uses ionizing radiation, which controls the cell growth by damaging the DNA. Since CLL is a category of blood cancer, the success rate of radiation therapy is low because radiation therapy is done by introducing a specific area (where tumor cells are located) to the ionizing radiation as blood flows all over the body, it is not possible to treat with radiation. Most importantly, it has a probability of killing the normal cells as well [6].

\section{Immunotherapy}

This is the most promising treatment for CLL where genetically engineered lymphocytes (T-cells) are used to kill the tumor cells. This therapy is very specific as it targets only the tumor cells and it is less harm to the normal cells [9]. By seeing the drawbacks of other therapies, CAR-T-cells are the source of immunotherapy for treating CLL $[7,8]$ effectively. 
Structure of CAR-T-cells

CAR-T-cells are composed of three portions they are ectodomain, endodomain, and transmembrane domain [15]. The overall CAR-T-cells are composed of a light chain $\left(\mathrm{V}_{\mathrm{L}}\right)$, a heavy chain $\left(\mathrm{V}_{\mathrm{H}}\right)$, hinge region, and transmembrane domain which are a lipid bilayer. The structure of CART-cells is given in Fig. 1.

\section{Ectodomain}

The ectodomain is a membrane protein present on the outer region of cytoplasm. It is composed of three parts; antigen recognition region, spacer, and signal peptide $[16,79]$. The signal peptide is a single-chain variable fragment ( $\mathrm{scFv}$ ) in which a portion of heavy and light chain of immunoglobulin (Ig) is fused by a linker [17]. The linker is hydrophilic, and for flexibility, the amino acids glycine and serine are present [18]. The antigen recognition domain is scFv with a basic ectodomain and more exotic recognition components. The tumor antigen will bind in the ectodomain region. The spacer is an intermediate which connects the transmembrane domain and ectodomain. The basic form of spacer is the IgG1's hinge region [20].

\section{Transmembrane domain}

The transmembrane domain plays an important role in the stability of the receptor molecule. The transmembrane is hydrophobic $\alpha$-helix which is the secondary structure of protein where $\mathrm{H}$ bond from the $\mathrm{N}-\mathrm{H}$ group is donated as a $\mathrm{C}=0$ group of the amino acid which is present around the membrane $[19,22]$. Initially, CD3- $\zeta$ was used as the domain as they resemble the normal T-cell receptor, but comparatively CD28 is the most effective one. These CDs are the proteins that are expressed in T-cells and they stimulate the signal which results in activation of T-cells [21].

\section{Endodomain}

The endodomain is present in the cytoplasm of the cell. It is the functional terminal of the receptor and is activated by CD3- $\zeta$ which presents in the ectodomain. The CD3- $\zeta$ contains immunoreceptor tyrosine-based activation motif and the efficiency is quite less, and hence, a costimulating signal domain is needed [68]. To satisfy these conditions, the molecules such as CD28, CD134, CD137, and CD27 are included in the CAR-T-cells to enhance the direct costimulation after the binding of tumor antigen to the CAR-T-cells [23]

\section{Production of CAR-T-cells}

The production of CAR-T-cells involves various steps. The most important step is quality control testing throughout the process. The process is briefly explained and the flow is depicted in Fig. 2.

Initially, the leukocytes are taken either from the patient or from the donor's blood from the process called leukapheresis [24]. In this

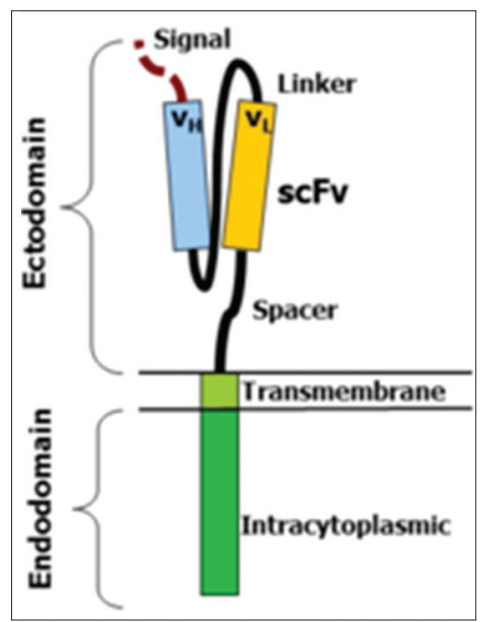

Fig. 1: Structure of chimeric antigen receptor-T-cells process, the blood is drawn to the apheresis where the components of the blood are separated by centrifugation. Anticoagulants are added during this process [25] and the leukocytes are retrieved. Second, the T-cells are separated from other components of leukocytes by enriching and washing. This process helps in removing the anticoagulants that were added in the previous step. Now, the CD4 and CD8 subsets in the T-cells are separated by specific antibody beats conjugates which are also called as marker [26]. The CD4 is a T helper cell which has CD4 glycoprotein at their surface and CD8 is a cytotoxic cell which contains a glycoprotein. The T-cells will be activated for proliferation and growth. The activation of T-cells can be done by three methods; they are as follows [37].

1. Monoclonal antibody and interleukins (ILs)

2. Magnetic beads coated with antibody

3. Artificial antigen presenting cells.

\section{Monoclonal antibody and IL}

In this method, a monoclonal antibody anti-CD3 and IL-2 which is a type of cytokine is added to the T-cells to develop proliferation $[27,84]$.

\section{Magnetic beads coated with antibody}

Anti-CD3 or CD28 is coated on magnetic beads resulting in the artificial antigen presenting particles [80]. The superparamagnetic beads are of diameter $4.5 \mu \mathrm{m}$ and are removed efficiently with a strong electromagnet, leaving $<100$ residual beads per $3 \times 10^{6}$ cells at the end of production. The beads are used continuously to proliferate the T-cells during the expansion [39]. This method results in a very strong activation of T-cells when compared to the use of monoclonal antibody and IL. The usage of magnetic beads is more convenient as they are removed easily after the proliferation of T-cells $[38,40]$.

\section{Artificial antigen presenting cells}

The other ways to activate the T-cells are using non-viable antigen presenting cells. These cells present the antigen on its surface and stimulate the T-cells $[28,100]$.

\section{GENE DELIVERY}

Gene delivery will be done either by viral method of gene transfer or through the plasmid mode of transfer. In CAR-T-cell therapy, viral vectors are used in gene delivery, where either lentiviruses or retroviruses are used for gene delivery [99]. The vector expresses the gene of CAR which is formed by combining the head of the antibody $\left(\mathrm{V}_{\mathrm{H}}\right.$ and $\left.\mathrm{V}_{\mathrm{L}}\right)$ and the T-cell signaling motif [37].

\section{Viral transduction}

High efficiency is obtained from viral transduction [41,78]. Since the retrovirus transduces the divided and proliferated cells, where activated T-cells are used. The CD28 signaling domain and CD3- $\zeta$ are combined together with the $\mathrm{scFv}$ to form the CAR gene and then transduced to the lentiviral vector. This is specific to the CD19 cells that are mainly present in B-lymphocytes, which are the chronic lymphocyte leukemia tumor cells. The viral vector encoding CAR gene after the entry of the target region, it results in CAR-Tcells [42].

\section{Plasmid-based gene delivery}

In plasmid-based gene delivery, the gene transposon system is used. A transposon is the sequence of DNA, which can change its position either by insertion or excision within the genome by transposase enzyme. The CAR transgene is inserted into the plasmid, and then, the plasmid is inserted into the T-cell genome. After the transformation studies, CAR-T-cells are produced and the cells are injected into the patient's body [43-46]. The CAR-T-cells lyse the CD19-positive targets, and the release of cytokines will activate the cellular components of the adaptive and innate immune system for enhancing the tumor rejection [83]. 


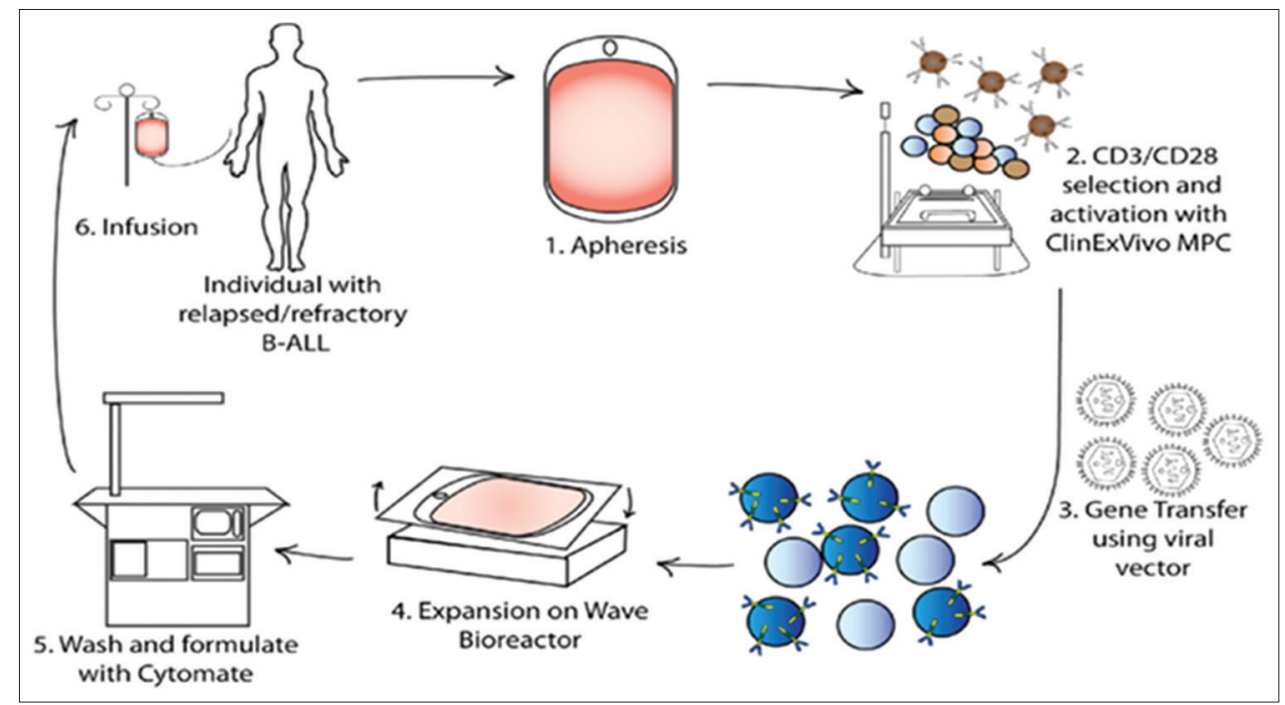

Fig. 2: The production process of chimeric antigen receptor-T-cells

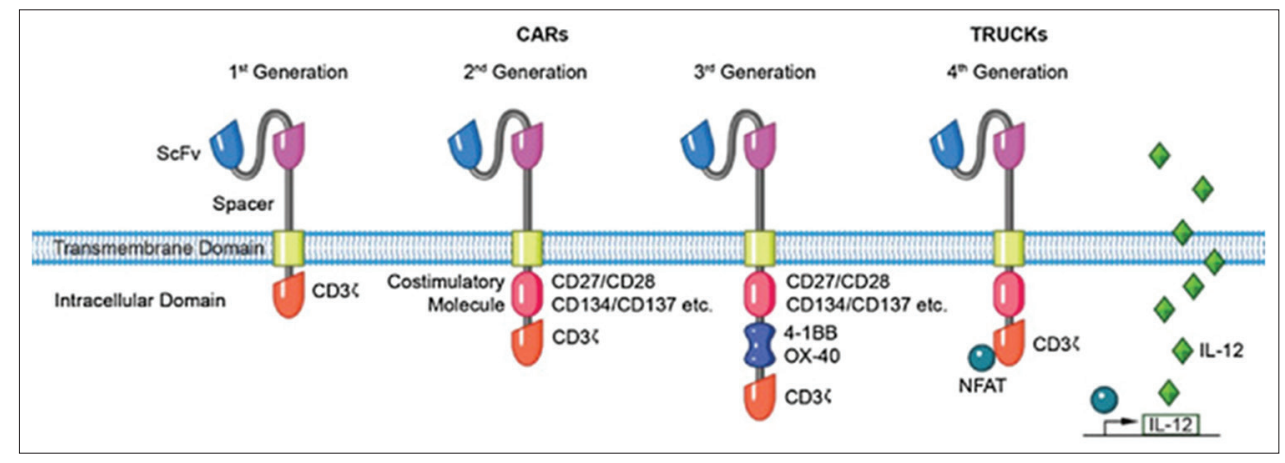

Fig. 3: Evolution of CAR-T-cells

\section{CAR-T-cell evolution}

The CAR-T-cells have been evolving since the initial development of immunotherapy. There are four generations of CAR-T-cells, which is depicted in Fig. 3. The structure differs from each other by the changes in the position of endodomain.

\section{First generation}

The first generation consists of simple structure, CD3- $\zeta$ which is present in the endodomain, a primary signal transmitter $[29,30,69]$. This type of CAR-T-cells is less efficient as they cannot produce enough amounts of cytokines. Hence, IL-2 should be added to it. Thus, the first-generation CAR-T-cell which is transfected with single chain receptors is benefitted only by the accompany of cytokines [31]. The transmembrane domain of CAR-T-cell consists of either homologous or heterologous dimer of CD3, CD8, and CD28 [32]. However, the first-generation CAR-T-cells did not give satisfied outcomes due to insufficient production of cytokines.

\section{Second generation}

In the second generation, the CAR-T-cell dual signal has been used for T-cell activation. Three receptors are included in this generation; they are antigen receptor, cytokine receptor, and costimulatory receptor. The T-cell antigen receptor is present on the ectodomain where the first signal is received after the antigen presenting cells bonded with it. The costimulatory receptor is present in the endodomain which contains CD28/CD137/CD27/CD134 [33,34,85,101]. The CD137 can maintain and strengthen the production of the IL-2 cytokine to destroy the tumor cells [82].

\section{Third Generation}

In this generation, an extra signaling domain has been added to already existing second-generation CAR-T-cells. This signal domain is of OX40 or 41BB to increase the potential of the production of the cytokines [35]. This CAR-T-cell is predominantly used in the treatment of lymphoma and colon cancer $[36,81]$.

\section{Fourth generation}

This CAR-T-cell has scFv in ectodomain, $\mathrm{CD} 3-\zeta$ in transmembrane domain, and in endodomain $\mathrm{CD} 3-\zeta, \mathrm{CD} 28$, as a costimulatory and additionally has a modified inducible expression cassette for a transgenic protein-like cytokine is present. These are called T-cell redirected for universal cytokine (TRUCKs)-mediated killing. It activates T-cells and also activates and engages the innate immune cells to terminate the antigen-negative tumor cells. To engineer these TRUCKs, two transgenes require one for the CAR and the other for inducible cytokines. Therefore, the CAR-T-cells were additionally engineered with a nuclear factor of the activated T-cell-responsive expression cassette for the inducible expression of a transgenic cytokine, for example, IL-2. These TRUCK T-cells can also be used for treating viral infection, autoimmune diseases, and metabolic disorders $[70,71]$.

\section{Various antigens being targeted by CAR-T-cells}

The CAR-T-cells are not only for treating CLL but also used for the treatment of various cancers.

Table 1 gives the information about the various cancers that can be treated by CARs [48-65,86-98]. 
Table 1: Cancer and their corresponding CAR-T-cell type

\begin{tabular}{|c|c|c|c|}
\hline S. No. & Cancer type & Antigen to be targeted & Receptor type \\
\hline 1 & Ovarian cancer & $\alpha$-Folate receptor & ScFv-FceRI $\gamma$ \\
\hline 2 & Acute lymphocytic leukemia & CD19 & scFv-41BB-CD3- $\zeta$ \\
\hline 3 & Renal cell carcinoma & CAIX & scFv-CD4-FceRI $\gamma$ \\
\hline 4 & Pancreatic adenocarcinoma & CD24 & scFv-CD28-FceRI $\gamma$ \\
\hline 5 & Breast cancer & Erb-B2 & scFv-CD28-CD3- $\zeta$ \\
\hline 6 & Cervical cancer & CD44v7/8 & scFv-CD28-CD3- $\zeta$ \\
\hline 7 & Ovarian cancer & FBP & scFv-FceRI $\gamma$ (alloantigen) \\
\hline 9 & Neuroblastoma & $\mathrm{G}_{\mathrm{D} 2}$ & scFv-CD28-0X40-CD3- $\zeta$ \\
\hline 10 & Prostate cancer, colon cancer & Erb-B2 & scFv-FceRI $\gamma$ \\
\hline 11 & Lymphomas & CD20 & scFv-CD28-CD3- $\zeta$ \\
\hline 12 & B-cell malignancies & CD20 & scFv-CD4-CD3- $\zeta^{\jmath}$ \\
\hline 13 & B-cell lymphomas & $\mathrm{CD} 20$ & scFv-CD3- $\zeta$ \\
\hline 14 & CLL & CD23 & scFv-CD28-CD3- $\zeta$ \\
\hline 15 & Epithelial cancer & $\alpha$-Folate receptor & scFv-41BB-CD3-לे \\
\hline 16 & Non-Hodgkin lymphoma & CD38 & scFv-41BB-CD3-ל \\
\hline 19 & Melanoma & HMW-MAA & $\mathrm{scFv}-\mathrm{CD} 3-\zeta$ \\
\hline 20 & Glioblastoma & IL-13R $\alpha 2$ & IL-13-CD3- $\zeta$ \\
\hline 21 & AML & CD33 & scFv-CD28-CD3- $\zeta$ \\
\hline
\end{tabular}

CLL: Chronic lymphocytic leukemia, scFv: Single-chain variable fragment, AML: Acute myeloid leukemia, HMW-MAA: High-molecular- weight melanoma-associated antigen, CAR-T: Chimeric antigen receptor T

\section{CONCLUSION}

The treatment for cancer using CAR-T-cells has given many promising outcomes. Not only CLL but also various cancers, viral disease and genetic disorders can also be cured without any side effects. The CAR-Tcells have been successfully used for treating all kinds of hematological cancers. The functionality of the CAR-T-cells can be effectively increased by modifying the domain of the CAR.

\section{FUTURE PERSPECTIVES}

The CAR-T-cells are "living drug," by manipulating their domain structures the applications can be broadened. These can be used for treating many genetic disorders and immunodeficiency disorders. The CAR-T-cells are more specific in nature when compared to chemotherapy and radiation therapy, and the side effects are also less when compared to others. Hence, the application of these cells can be used in various clinical trials for further development.

\section{ACKNOWELDGMENT}

The authors thank the Vels Institute of Science, Technology and Advanced Studies, management for constantly supporting in writing the review article successfully.

\section{AUTHORS' CONTRIBUTION}

Both the authors have contributed equally for bringing this review article effectively.

\section{CONFLICTS OF INTEREST}

The authors do not have any conflicts of interest.

\section{REFERENCES}

1. Kipps TJ, Stevenson FK, Wu CJ, Croce CM, Packham G, Wierda WG, et al. Chronic lymphocytic leukaemia. Nat Rev Dis Primers 2017;3:16096.

2. Ghia P, Ferreri AM, Caligaris-Cappio F. Chronic lymphocytic leukemia. Crit Rev Oncol Hematol 2007;64:234-46.

3. Tam CS, O'Brien S, Wierda W, Kantarjian H, Wen S, Do KA, et al. Long-term results of the fludarabine, cyclophosphamide, and rituximab regimen as initial therapy of chronic lymphocytic leukemia. Blood 2008; 112:975-80.

4. Keating MJ, O'Brien S, Albitar M, Lerner S, Plunkett W, Giles F, et al. Early results of a chemoimmunotherapy regimen of fludarabine, cyclophosphamide, and rituximab as initial therapy for chronic lymphocytic leukemia. J Clin Oncol 2005;23:4079-88.

5. Janssens A, Foa R, Keating M, Tatt L, Carr E. Rituximab for chronic lymhocytic leukemia in treatment-naïve and treatment-experienced patients. Contemp Oncol 2012;44:47-52

6. Whang-Peng J, Knutsen T, Brereton HD, O’Donnell JF. Acute non-lymphocytic leukemia and acute myeloproliferative syndrome following radiation therapy for non-hodgkin's lymphoma and chronic lymphocytic leukemia. Cytogenetic studies. Cancer 1979;44:1592-600.

7. Wierda WG, O'Brien S. Immunotherapy of chronic lymphocytic leukemia. Exp Rev Anticancer Ther 2001;1:73-83.

8. Morgan RA, Dudley ME, Wunderlich JR, Hughes MS, Yang JC, Sherry RM, et al. Cancer regression in patients after transfer of genetically engineered lymphocytes. Science 2006;314:126-9.

9. Srivastava S, Riddell SR. Engineering CAR-T cells: Design concepts. Trends Immunol 2015;36:494-502.

10. Yonemoto J. The effects of dioxin on reproduction and development. Ind Health 2000:38:259-68.

11. Ngo AD, Taylor R, Roberts CL, Nguyen TV. Association between agent orange and birth defects: Systematic review and meta-analysis. Int $\mathrm{J}$ Epidemiol 2006;35:1220-30.

12. Palmer MG. The case of agent orange. Contemp Southeast Asia 2007;1:172-95.

13. Richardson DB, Wing S, Schroeder J, Schmitz-Feuerhake I, Hoffmann W. Ionizing radiation and chronic lymphocytic leukemia. Environ Health Perspect 2005;113:1-5.

14. Hartmann J, Schüßler-Lenz M, Bondanza A, Buchholz CJ. Clinical development of CAR T cells-challenges and opportunities in translating innovative treatment concepts. EMBO Mol Med 2017:9:1183-97.

15. Liu J, Zhong JF, Zhang X, Zhang C. Allogeneic CD19-CAR-T cell infusion after allogeneic hematopoietic stem cell transplantation in B cell malignancies. J Hematol Oncol 2017;10:35.

16. Ramos CA, Dotti G. Chimeric antigen receptor (CAR)-engineered lymphocytes for cancer therapy. Expert Opin Biol Ther 2011;11:855-73.

17. Zhang C, Liu J, Zhong JF, Zhang X. Engineering CAR-T cells. Biomark Res 2017;5:22.

18. Baldo BA. Chimeric fusion proteins used for therapy: Indications, mechanisms, and safety. Drug Saf 2015;38:455-79.

19. Tasian SK, Gardner RA. CD19-redirected chimeric antigen receptormodified T cells: A promising immunotherapy for children and adults with B-cell acute lymphoblastic leukemia (ALL). Ther Adv Hematol 2015;6:228-41.

20. Hombach A, Hombach AA, Abken H. Adoptive immunotherapy with genetically engineered T cells: Modification of the IgG1 fc 'spacer' domain in the extracellular moiety of chimeric antigen receptors avoids 'off-target' activation and unintended initiation of an innate immune response. Gene Ther 2010;17:1206-13

21. Loskog A, Giandomenico V, Rossig C, Pule M, Dotti G, Brenner MK, 
et al. Addition of the CD28 signaling domain to chimeric T-cell receptors enhances chimeric $\mathrm{T}$-cell resistance to $\mathrm{T}$ regulatory cells. Leukemia 2006;20:1819-28

22. Abrusán G, Marsh JA. Alpha helices are more robust to mutations than beta strands. PLoS Comput Biol 2016;12:e1005242.

23. Irving BA, Weiss A. The cytoplasmic domain of the T cell receptor zeta chain is sufficient to couple to receptor-associated signal transduction pathways. Cell 1991;64:891-901.

24. Smith JW. Apheresis techniques and cellular immunomodulation. Ther Apher 1997;1:203-6.

25. Lee G, Arepally GM. Anticoagulation techniques in apheresis: From heparin to citrate and beyond. J Clin Apher 2012;27:117-25.

26. Riddell SR, Sommermeyer D, Berger C, Liu LS, Balakrishnan A, Salter A, et al. Adoptive therapy with chimeric antigen receptormodified T cells of defined subset composition. Cancer J 2014;20:141-4.

27. Levine BL, Bernstein WB, Connors M, Craighead N, Lindsten T, Thompson CB, et al. Effects of CD28 costimulation on long-term proliferation of CD4+ T cells in the absence of exogenous feeder cells. J Immunol 1997;159:5921-30

28. Suhoski MM, Golovina TN, Aqui NA, Tai VC, Varela-Rohena A, Milone MC, et al. Engineering artificial antigen-presenting cells to express a diverse array of co-stimulatory molecules. Mol Ther 2007;15:981-8.

29. Gross G, Waks T, Eshhar Z. Expression of immunoglobulin-T-cell receptor chimeric molecules as functional receptors with antibody-type specificity. Proc Natl Acad Sci U S A 1989;86:10024-8.

30. Eshhar Z, Waks T, Gross G, Schindler DG. Specific activation and targeting of cytotoxic lymphocytes through chimeric single chains consisting of antibody-binding domains and the gamma or zeta subunits of the immunoglobulin and T-cell receptors. Proc Natl Acad Sci U S A 1993;90:720-4.

31. Brocker T. Chimeric fv-zeta or fv-epsilon receptors are not sufficient to induce activation or cytokine production in peripheral T cells. Blood 2000;96:1999-2001

32. Bridgeman JS, Hawkins RE, Bagley S, Blaylock M, Holland M, Gilham DE, et al. The optimal antigen response of chimeric antigen receptors harboring the CD3zeta transmembrane domain is dependent upon incorporation of the receptor into the endogenous TCR/CD3 complex. J Immunol 2010;184:6938-49.

33. Savoldo B, Ramos CA, Liu E, Mims MP, Keating MJ, Carrum G, et al. CD28 costimulation improves expansion and persistence of chimeric antigen receptor-modified $\mathrm{T}$ cells in lymphoma patients. J Clin Invest 2011;121:1822-6.

34. Milone MC, Fish JD, Carpenito C, Carroll RG, Binder GK, Teachey D, et al. Chimeric receptors containing CD137 signal transduction domains mediate enhanced survival of $\mathrm{T}$ cells and increased antileukemic efficacy in vivo. Mol Ther 2009;17:1453-64.

35. Marin V, Pizzitola I, Agostoni V, Attianese GM, Finney H, Lawson A, et al. Cytokine-induced killer cells for cell therapy of acute myeloid leukemia: Improvement of their immune activity by expression of CD33-specific chimeric receptors. Haematologica 2010;95:2144-52.

36. Till BG, Jensen MC, Wang J, Qian X, Gopal AK, Maloney DG, et al. CD20-specific adoptive immunotherapy for lymphoma using a chimeric antigen receptor with both CD28 and 4-1BB domains: Pilot clinical trial results. Blood 2012;119:3940-50.

37. Vormittag P, Gunn R, Ghorashian S, Veraitch FS. A guide to manufacturing CAR $\mathrm{T}$ cell therapies. Curr Opin Biotechnol 2018;53:164-81

38. Kalos M, Levine BL, Porter DL, Katz S, Grupp SA, Bagg A, et al. $\mathrm{T}$ cells with chimeric antigen receptors have potent antitumor effects and can establish memory in patients with advanced leukemia. Sci Transl Med 2011;3:95ra73

39. Hollyman D, Stefanski J, Przybylowski M, Bartido S, BorquezOjeda $\mathrm{O}$, Taylor $\mathrm{C}$, et al. Manufacturing validation of biologically functional T cells targeted to CD19 antigen for autologous adoptive cell therapy. J Immunother 2009;32:169-80.

40. Barrett DM, Singh N, Liu X, Jiang S, June CH, Grupp SA, et al. Relation of clinical culture method to T-cell memory status and efficacy in xenograft models of adoptive immunotherapy. Cytotherapy 2014;16:619-30.

41. Guo B, Chen M, Han Q, Hui F, Dai H, Zhang W, et al. CD138-directed adoptive immunotherapy of chimeric antigen receptor (CAR)-modified $\mathrm{T}$ cells for multiple myeloma. J Cell Immunother 2016;2:28-35.

42. Ghorashian S, Pule M, Amrolia P. CD19 chimeric antigen receptor $\mathrm{T}$ cell therapy for haematological malignancies. $\mathrm{Br} \mathrm{J}$ Haematol 2015;169:463-78.

43. Ivics Z, Hackett PB, Plasterk RH, Izsvák Z. Molecular reconstruction of sleeping beauty, a tc1-like transposon from fish, and its transposition in human cells. Cell 1997;91:501-10.

44. Kebriaei P, Huls H, Singh H, Olivares S, Figliola M, Maiti S, et al. Adoptive therapy using sleeping beauty gene transfer system and artificial antigen presenting cells to manufacture $T$ cells expressing CD19-specific chimeric antigen receptor. Blood 2014;124:311.

45. Singh H, Figliola MJ, Dawson MJ, Huls H, Olivares S, Switzer K, et al. Reprogramming CD19-specific T cells with IL-21 signaling can improve adoptive immunotherapy of B-lineage malignancies. Cancer Res 2011;71:3516-27.

46. Kebriaei P, Ciurea SO, Huls MH, Singh H, Olivares S, Su S, et al. Preemptive donor lymphocyte infusion with CD19-directed, CAR-modified $\mathrm{T}$ cells infused after allogeneic hematopoietic cell transplantation for patients with advanced CD19+ malignancies. Blood 2015;126:862

47. Park B, Yoo KH, Kim C. Hematopoietic stem cell expansion and generation: The ways to make a breakthrough. Blood Res 2015;50:194-203.

48. Sadelain M, Brentjens R, Rivière I. The basic principles of chimeric antigen receptor design. Cancer Discov 2013;3:388-98.

49. Sadelain M, Rivière I, Brentjens R. Targeting tumours with genetically enhanced T lymphocytes. Nat Rev Cancer 2003;3:35-45.

50. Gong MC, Latouche JB, Krause A, Heston WD, Bander NH, Sadelain M. Cancer patient $\mathrm{T}$ cells genetically targeted to prostatespecific membrane antigen specifically lyse prostate cancer cells and release cytokines in response to prostate-specific membrane antigen. Neoplasia 1999;1:123-7.

51. Kowolik CM, Topp MS, Gonzalez S, Pfeiffer T, Olivares S, Gonzalez N, et al. CD28 costimulation provided through a CD19-specific chimeric antigen receptor enhances in vivo persistence and antitumor efficacy of adoptively transferred T cells. Cancer Res 2006;66:10995-1004.

52. Rosenberg SA, Restifo NP, Yang JC, Morgan RA, Dudley ME. Adoptive cell transfer: A clinical path to effective cancer immunotherapy. Nat Rev Cancer 2008;8:299-308.

53. Sadelain M, Brentjens R, Rivière I. The promise and potential pitfalls of chimeric antigen receptors. Curr Opin Immunol 2009;21:215-23.

54. Zhou G, Levitsky H. Towards curative cancer immunotherapy: Overcoming posttherapy tumor escape. Clin Dev Immunol 2012;2012:124187.

55. Chinnasamy D, Yu Z, Kerkar SP, Zhang L, Morgan RA, Restifo NP, et al. Local delivery of interleukin-12 using $\mathrm{T}$ cells targeting VEGF receptor-2 eradicates multiple vascularized tumors in mice. Clin Cancer Res 2012;18:1672-83.

56. Lupo-Stanghellini MT, Provasi E, Bondanza A, Ciceri F, Bordignon C, Bonini $\mathrm{C}$, et al. Clinical impact of suicide gene therapy in allogeneic hematopoietic stem cell transplantation. Hum Gene Ther 2010;21:241-50.

57. Di Stasi A, Tey SK, Dotti G, Fujita Y, Kennedy-Nasser A, Martinez C, et al. Inducible apoptosis as a safety switch for adoptive cell therapy. N Engl J Med 2011;365:1673-83

58. Kochenderfer JN, Wilson WH, Janik JE, Dudley ME, StetlerStevenson M, Feldman SA, et al. Eradication of B-lineage cells and regression of lymphoma in a patient treated with autologous $\mathrm{T}$ cells genetically engineered to recognize CD19. Blood 2010;116:4099-102.

59. Huang X, Wilber A, McIvor RS, Zhou X. DNA transposons for modification of human primary $\mathrm{T}$ lymphocytes. Methods Mol Biol 2009;506:115-26.

60. Ponomarev V, Doubrovin M, Lyddane C, Beresten T, Balatoni J, Bornman W, et al. Imaging TCR-dependent NFAT-mediated T-cell activation with positron emission tomography in vivo. Neoplasia 2001;3:480-8

61. Suerth JD, Schambach A, Baum C. Genetic modification of lymphocytes by retrovirus-based vectors. Curr Opin Immunol 2012;24:598-608.

62. Birkholz K, Hombach A, Krug C, Reuter S, Kershaw M, Kämpgen E, et al. Transfer of mRNA encoding recombinant immunoreceptors reprograms $\mathrm{CD} 4+$ and $\mathrm{CD} 8+\mathrm{T}$ cells for use in the adoptive immunotherapy of cancer. Gene Ther 2009;16:596-604.

63. Urbanska K, Lanitis E, Poussin M, Lynn RC, Gavin BP, Kelderman S, et al. A universal strategy for adoptive immunotherapy of cancer through use of a novel T-cell antigen receptor. Cancer Res 2012;72:1844-52.

64. Mavilio F, Ferrari G, Rossini S, Nobili N, Bonini C, Casorati G, et al. Peripheral blood lymphocytes as target cells of retroviral vectormediated gene transfer. Blood 1994;83:1988-97.

65. Bunnell BA, Muul LM, Donahue RE, Blaese RM, Morgan RA. Highefficiency retroviral-mediated gene transfer into human and nonhuman primate peripheral blood lymphocytes. Proc Natl Acad Sci U S A 1995;92:7739-43.

66. Ashokkumar DA, Praful DB. Chronic myelogenous leukemia: A review and update of current and future therapy. Int J Pharm Pharm 
Sci 2016;2016:35-46.

67. Minakshi G, Jyoti D, Kumar MR, Harish D. Therapies in cancer treatment: An overview. Int J Pharm Pharm Sci 2015;7:1-9.

68. Yu S, Li A, Liu Q, Li T, Yuan X, Han X, et al. Chimeric antigen receptor T cells: A novel therapy for solid tumors. J Hematol Oncol 2017;10:78.

69. Maus MV, June CH. Making better chimeric antigen receptors for adoptive T-cell therapy. Clin Cancer Res 2016;22:1875-84.

70. Chmielewski M, Abken H. CAR T cells transform to trucks: Chimeric antigen receptor-redirected $\mathrm{T}$ cells engineered to deliver inducible IL12 modulate the tumour stroma to combat cancer. Cancer Immunol Immunother 2012;61:1269-77.

71. Chmielewski M, Abken H. TRUCKs: The fourth generation of CARs. Expert Opin Biol Ther 2015;15:1145-54.

72. Sha HH, Wang DD, Yan DL, Hu Y, Yang SJ, Liu SW, et al. Chimaeric antigen receptor T-cell therapy for tumour immunotherapy. Biosci Rep 2017;37:BSR20160332.

73. Rozman C, Montserrat E. Chronic lymphocytic leukemia. N Engl J Med 1995;333:1052-7.

74. Hallek M, Fischer K, Fingerle-Rowson G, Fink AM, Busch R, Mayer J, et al. Addition of rituximab to fludarabine and cyclophosphamide in patients with chronic lymphocytic leukaemia: A randomised, openlabel, phase 3 trial. Lancet 2010;376:1164-74.

75. Rai KR, Peterson BL, Appelbaum FR, Kolitz J, Elias L, Shepherd L, et al. Fludarabine compared with chlorambucil as primary therapy for chronic lymphocytic leukemia. N Engl J Med 2000;343:1750-7.

76. Ott MG, Zober A. Cause specific mortality and cancer incidence among employees exposed to 2, 3, 7, 8-TCDD after a 1953 reactor accident. Occup Environ Med 1996;53:606-12.

77. Diehl LF, Karnell LH, Menck HR. The American college of surgeons commission on cancer and the American cancer society. The national cancer data base report on age, gender, treatment, and outcomes of patients with chronic lymphocytic leukemia. Cancer 1999;86:2684-92.

78. Vannucci L, Lai M, Chiuppesi F, Ceccherini-Nelli L, Pistello M. Viral vectors: A look back and ahead on gene transfer technology. New Microbiol 2013;36:1-22.

79. Wang Z, Wu Z, Liu Y, Han W. New development in CAR-T cell therapy. J Hematol Oncol 2017;10:53.

80. Maude SL, Frey N, Shaw PA, Aplenc R, Barrett DM, Bunin NJ, et al. Chimeric antigen receptor $\mathrm{T}$ cells for sustained remissions in leukemia. N Engl J Med 2014;371:1507-17

81. Cartellieri M, Bachmann M, Feldmann A, Bippes C, Stamova S, Wehner R, et al. Chimeric antigen receptor-engineered $\mathrm{T}$ cells for immunotherapy of cancer. Bio Med Res Int 2010;2010:13.

82. Barrett DM, Singh N, Porter DL, Grupp SA, June CH. Chimeric antigen receptor therapy for cancer. Annu Rev Med 2014;65:333-47.

83. Porter DL, Levine BL, Kalos M, Bagg A, June CH. Chimeric antigen receptor-modified T cells in chronic lymphoid leukemia. N Engl J Med 2011;365:725-33.

84. Kaye J, Gillis S, Mizel SB, Shevach EM, Malek TR, Dinarello CA, et al. Growth of a cloned helper T cell line induced by a monoclonal antibody specific for the antigen receptor: Interleukin 1 is required for the expression of receptors for interleukin 2. J Immunol 1984;133:1339-45.

85. Van Der Stegen SJ, Hamieh M, Sadelain M. The pharmacology of second-generation chimeric antigen receptors. Nat Rev Drug Discov 2015;14:499.
86. Quintarelli C, Vera JF, Savoldo B, Giordano Attianese GM, Pule M, Foster AE, et al. Co-expression of cytokine and suicide genes to enhance the activity and safety of tumor-specific cytotoxic $\mathrm{T}$ lymphocytes. Blood 2007;110:2793-802.

87. Hsu C, Jones SA, Cohen CJ, Zheng Z, Kerstann K, Zhou J, et al. Cytokine-independent growth and clonal expansion of a primary human CD8+ T-cell clone following retroviral transduction with the IL-15 gene. Blood 2007;109:5168-77.

88. Foster AE, Leen AM, Lee T, Okamura T, Lu A, Vera J, et al. Autologous designer antigen-presenting cells by gene modification of $\mathrm{T}$ lymphocyte blasts with IL-7 and IL-12. J Immunother 2007;30:506-16.

89. Kaka AS, Shaffer DR, Hartmaier R, Leen AM, Lu A, Bear A, et al. Genetic modification of T cells with IL-21 enhances antigen presentation and generation of central memory tumor-specific cytotoxic T-lymphocytes. J Immunother 2009;32:726-36

90. Kerkar SP, Muranski P, Kaiser A, Boni A, Sanchez-Perez L, Yu Z, et al. Tumor-specific CD8+ $\mathrm{T}$ cells expressing interleukin-12 eradicate established cancers in lymphodepleted hosts. Cancer Res 2010;70:6725-34.

91. Ho WY, Blattman JN, Dossett ML, Yee C, Greenberg PD. Adoptive immunotherapy: Engineering $\mathrm{T}$ cell responses as biologic weapons for tumor mass destruction. Cancer Cell 2003;3:431-7.

92. Kohn DB, Dotti G, Brentjens R, Savoldo B, Jensen M, Cooper LJ, et al. CARs on track in the clinic. Mol Ther 2011;19:432-8.

93. Davila ML, Brentjens R, Wang X, Rivière I, Sadelain M. How do CARs work? Early insights from recent clinical studies targeting CD19. Oncoimmunology 2012;1:1577-83.

94. Hülsmeyer M, Chames P, Hillig RC, Stanfield RL, Held G, Coulie PG, et al. A major histocompatibility complex-peptiderestricted antibody and t cell receptor molecules recognize their target by distinct binding modes: Crystal structure of human leukocyte antigen (HLA)-A1-MAGE-A1 in complex with FAB-HYB3. J Biol Chem 2005;280:2972-80.

95. Denkberg G, Reiter Y. Recombinant antibodies with T-cell receptorlike specificity: Novel tools to study MHC class I presentation. Autoimmun Rev 2006;5:252-7.

96. Kloss CC, Condomines M, Cartellieri M, Bachmann M, Sadelain M. Combinatorial antigen recognition with balanced signaling promotes selective tumor eradication by engineered $\mathrm{T}$ cells. Nat Biotechnol 2013;31:71-5.

97. Hanada K, Restifo NP. Double or nothing on cancer immunotherapy. Nat Biotechnol 2013;31:33-4.

98. Li YS, Hayakawa K, Hardy RR. The regulated expression of B lineage associated genes during $\mathrm{B}$ cell differentiation in bone marrow and fetal liver. J Exp Med 1993;178:951-60.

99. Levine BL, Humeau LM, Boyer J, MacGregor RR, Rebello T, Lu X, et al. Gene transfer in humans using a conditionally replicating lentiviral vector. Proc Natl Acad Sci U S A 2006;103:17372-7.

100. Levine BL, Bernstein W, Craighead N, Thompson CB, Lindsten T, St Louis DC, et al. Ex vivo replicative potential of adult human peripheral blood CD4+ T cells. Transplant Proc 1997;29:2028.

101. Hay KA, Turtle CJ. Chimeric antigen receptor (CAR) T cells: Lessons learned from targeting of CD19 in B-cell malignancies. Drugs 2017;77:237-45 